Review Article

\title{
CONTEMPLATION OF SYMBIOTIC MICROBIAL BIOFILMS IN WASTEWATER TREATMENT
}

\author{
JUHI SHARMA ${ }^{1 \#, ~ P A W A N ~ K U M A R ~ J A I N ~}{ }^{1}$, VAISHALI VISHWAKARMA², ANKITA SHRIVASTAVA ${ }^{2}$ \\ ${ }^{1}$ School of Basic and Applied Sciences, Eklavya University, Damoh, ${ }^{2}$ St. Aloysius College, Jabalpur \\ Email: juhiv5360@gmail.com
}

Received: 04 Aug 2021, Revised and Accepted: 10 Oct 2021

\begin{abstract}
State of symbiosis is created among the species that are found in naturally existing biofilms. Biofilm formation provides protection against toxic shocks, mechanical stress, and predation. Biofilm can play an important role in wastewater treatment technologies and on the other hand could also lead to plague water. Biofilm-based treatments have been traditionally used for the treatment of water but the recent development in the stream has boosted the use of biofilm in various strategies of waste water treatment especially for strategies related to BOD and nutrients. However, the blueprint and execution of this idea is still being worked on due to the problems which arise in the implementation such as corroding pipes, increasing head loss, allowing pathogens to persist in distribution systems, and fouling membrane processes. Design for choice of species for biofilm processes in particular techniques is important wastewater treatment. All these data are essential to develop the performance, effectiveness and constancy of biofilm-based wastewater treatment strategies.
\end{abstract}

Keywords: Bacteria, Biofilm formation, Wastewater treatment, Fouling membrane, Bioreactor

(C) 2021 The Authors. Published by Innovare Academic Sciences Pvt Ltd. This is an open access article under the CC BY license (https://creativecommons.org/licenses/by/4.0/) DOI: https://dx.doi.org/10.22159/ijcpr.2021v13i6.1921 Journal homepage: https://innovareacademics.in/journals/index.php/ijcpr

\section{INTRODUCTION}

A congregation of microbial cells that is irreversibly linked with a surface is called a biofilm. The process of formation of biofilm occurs over a series of events leading to adaptation under diverse environmental and nutritional conditions [1,2] A mature biofilm is organized by a hydrated polymeric matrix, has a highly differentiated structure, being called mushroom and pillar-like assembly [3]. Biofilm formation is regulated by various genetic and environmental factors. Bacterial mobility, extracellular polysaccharides, cell membrane proteins and signalling molecules play significant roles in biofilm formation.

\section{Biofilm development: structure and function}

Biofilm matrix may be composed of acellular resources such as corrosion particles, mineral crystals, clay or silt particles, or blood components. Biofilms may cast on a wide variety of surfaces, including living tissues, indwelling medical devices, industrial or potable water system piping, or natural aquatic systems. Breakdown of different nutrients, such as phosphorus and nitrogen-containing compounds, carbonaceous materials as well as trapped pathogens are done by the microbial communities of biofilm from the wastewater. Biofilm development has following important steps (a) attachment (b) maturation and (c) detachment (dispersal)

\section{A. Attachment}

Primary adhesion of bacteria to the surface begins the formation of a mature biofilm and involves the reversible attachment of planktonic bacteria [4]. Cell surfaces have locomotor structures such as flagella, pili, fimbriae providing an advantage in biofilm formation. The direct primary adhesion to abiotic surfaces is mediated by non-specific physicochemical interactions (hydrodynamic forces, electrostatic interactions, Van der Waals forces and hydrophobic interactions) and the planktonic cells adhere to a surface randomly (Brownian motion and gravitational force) or in a directed way via chemotaxis, flagella motility and pili $[5,6]$. Motile bacteria can utilize flagella to overcome hydrodynamic and repulsive forces, which gives it a competitive advantage. The flagellar motility is important for initial attachment, as has been reported for many bacteria [7]. At this stage, the bacteria can bind to the biofilm lifestyle or vacate the surface and return to the planktonic lifestyle. After primary adhesion the next step is secondary adhesion, which links to an irreversible binding to the surface. The microorganisms begin to produce the EPS in this stage, forming micro colonies as it complexes with materials present on the surface firming up the links between the cells and the surface $[8,4]$. At this instant, the cells start to communicate through QS signals as there is no motility [9]. Surfaces which are rough, hydrophilic and coated deliver a better environment for most recurrent attachment and biofilm formation [10]. Microorganisms multiply into micro colonies encapsulating themselves in the EPSs.

\section{B. Maturation}

The maturation of biofilm occurs in response to increasing population density and high EPS production, this increases the biofilm thickness and the stability of the colony; cell division and adhesion of new planktonic cells are the two means by which the population growth takes place [8]. QS Signal and EPS build-up through continued cell division, are two factors essential for the maturation of biofilm. During biofilm formation many species of bacteria are able to communicate with one another through this mechanism called quorum sensing [11]. More than $90 \%$ of the dry mass in mature biofilms is characterized by EPS [12]. EPS components take account of polysaccharides, nucleic acids, proteins, lipids, and other biopolymers. EPS is responsible for scaffolding cells together, adhesion to surfaces and maintaining the threedimensional architecture of the biofilm. Moreover, the bacterial cell surrounded by EPS is protected against various stresses such as antimicrobials, host immune systems, oxidation and metallic cations [12]. Inside the biofilm, EPS retains quorum sensing (QS) signaling molecules, extracellular enzymes, and metabolic products. Therefore, EPS supports cell to cell communication and degrading substances [12, 13]. C--ells or small portions of the biofilm may detach and disperse after the maturation of biofilm, as a result of nutrient depletion, QS signaling or shearing of biofilm aggregates because of flow effects $[14,4]$.

\section{Dispersal}

After biofilm formation, the bacteria leave the biofilms itself on a regular basis so it can undergo rapid multiplication and dispersal. Detachment of planktonic bacterial cells from the biofilm is programmed and has a natural pattern. Sometimes bacteria are detached from the colony into the surrounding due to some mechanical stress, but in most cases some bacteria stop EPS production and are detached into the environment Dispersing of biofilm cells occurs either by detachment of newly formed cells from growing cells or due to flowing effects or due to quorumsensing [15]. The mode of biofilm dispersion affects the phenotypic 
character of organisms. Dispersed cells from the biofilm have the ability to hold its certain properties, like antibiotic in-sensitivity. The cells which are dispersed from biofilm as result of growth may return quickly to their normal planktonic phenotype. Alterations in nutrient availability, oxygen fluctuations, and increase in the toxic products or other stress -inducing conditions may also result in biofilm dispersion [16].

Acellular materials such as mineral crystals, corrosion particles, clay or silt particles as well as blood components (in case of bacterial biofilms present within the human body) might also be found in the matrix of biofilm [14]. There are channels for the circulation of nutrient and water within the matrix [12]; they also provide interspecies bacterial exchange or sharing of different metabolic substrates in biofilm. Under rigorously low nutrient conditions, bacteria can produce amino acids that cleave the structural polysaccharides allowing for detachment of cells from the biofilm hence modulating the structure of the biofilm [17]. EPS can incorporate large amounts of water into its structure by hydrogen bonding and hence is highly hydrated; it prevents desiccation in some natural biofilms. Nutrient availability, temperature, light, $\mathrm{pH}$, ionic strength, carbon source, and water content can alter the structure of biofilms [12]. By increasing cross-linkage between polysaccharides the structural veracity of the biofilm can be improved by cations [18]. Biofilm thickness could be affected by the number of component organisms. Biofilm architecture is constantly changing because of external and internal processes, and heterogeneous both in space and time. Structure may also be influenced from the host or environment by the interface of particles of non-microbial constituents. Another example of particle interactions with biofilms are minerals such as calcium carbonate, corrosion products such as iron oxides and soil particles collecting in biofilms of potable and industrial water systems.

\section{Factors affecting biofilm formation}

\section{Surface}

Surface geography greatly affects the ability of bacteria to adhere to a surface. Surface roughness reduces the shear force on bacterial cells and communities present in fluid at high flow rates, such as water pipes in industrial plants. A material surface will inevitably become conditioned or coated by polymers from the medium when exposed in an aqueous medium, and the consequential chemical modification will affect the rate and extent of microbial attachment. Furthermore, other factors influencing microbial attachment are such as charge, hydrophobicity and elasticity [19].

\section{pH}

The growth and development of bacteria and biofilm formation are greatly affected by the change in $\mathrm{pH}$ as it can overwhelm different mechanisms and have negative or killing effects on the microorganisms. For the majority of bacteria, the optimal $\mathrm{pH}$ for polysaccharide production is around 7, but it varies among different species.

\section{Salinity}

Salt tolerance in plants depends mainly on the capability of roots for (i) restricted or controlled uptake of $\mathrm{Na}^{+}$and $\mathrm{Cl}$-(ii) continued uptake of essential elements, particularly $\mathrm{K}^{+}$and $\mathrm{NO3}^{\text {. }}$

\section{Temperature and moisture content}

Limited water availability is typically the most critical factor to which terrestrial bacterial communities are exposed to including other environmental stress factors which exhibit the greatest effect on survival and activity of these communities.

\section{Nutrient availability}

Biofilm bacteria acquire nutrients by concentrating trace organics on surfaces by the extracellular polymers, using the waste products from their neighbours and secondary colonizers, and by using different enzymes to break down food supplies nutrients such as sucrose, phosphate, and calcium enhance biofilm formation as their concentrations increase

\section{Velocity, Turbulence and hydrodynamics}

The boundary layer is the area from the surface where no turbulent flow is experienced. Contained by this area, the flow velocity has been shown to be insufficient to remove biofilms. The area outside this layer is regarded as high levels of turbulent flow and has an influence on the attachment of cells to the surface. The size of the boundary layer is dependent on the flow velocity of water. The boundary layer decreases in size at high velocities, and the cells are exposed to a high turbulence level. Hydrodynamic conditions can power the formation, structure, thickness, mass, EPS production and metabolic activities of biofilms [20].

\section{Gene regulation and quorum sensing (QS)}

For cell attachment and detachment from biofilms cell-to-cell signalling, also termed QS signalling, has been proven to play an important role. Bacterial cells release a density-dependent chemical signal densely packed with an EPS matrix to mediate growth and development of biofilms on different surfaces. A transcriptional activator protein is used by QS that acts in concert with small auto inducers (AIs) signaling molecules to stimulate expression of target genes, resulting in changes in chemical behaviour. After amassing sufficient AIs, this form of intercellular communication serves to coordinate gene expression, morphological differentiation and the development responses of bacterial cells [21].

\section{Production of extracellular polymeric substances (EPSs)}

By bridging with multivalent cations and hydrophobic interactions EPSs aid in the formation of a gel-like network that keeps bacteria together in biofilms. In addition, EPSs also cause the adherence of biofilms to surfaces, flocculation and granulation, protect bacteria against harmful environmental conditions and enable bacteria to capture nutrients from the surroundings [22].

\section{Extracellular DNA (eDNA)}

A number of single and multispecies biofilms has extracellular DNA as a major constituent. Its role is very important in numerous stages of biofilm formation, such as initial bacterial adhesion, aggregation and microcolony formation that favors wastewater treatment. eDNA also helps strengthen biofilms, be responsible for protection to biofilms from physical stress, antibiotics and detergents as well as aids as an exceptional source of nutrients for biofilm growth [23].

\section{Divalent cations}

Latest studies showed that eDNA chelates divalent cations that help in the modification of bacterial cell surface properties and thus favor resistance of biofilms to detergents and antimicrobial agents [24]. In terrestrial and aquatic environments divalent cations such as $\mathrm{Ca}^{2+}$ are present in abundance; therefore, calcium may be one of the factors that bacteria sense during biofilm-associated growth. By associating negatively charged sites on extracellular polymers, divalent cations, such as those of calcium, play a critical role in the initial attachment of microbial aggregates of activated sludge flocs, anaerobic sludge granules and biofilms [25]. Biofilm can become denser and mechanically more stable by introducing more divalent cations which enhances the thickness of biofilm, as shown in current studies [26]. Calcium has been found acting as a cofactor for certain proteins and is also active in cell signaling, cellular and extracellular product formation, biofilm virulence, and alginate regulation [27].

\section{Bacterial, fungal and microalgal biofilms}

Biofilms are intricate surface-associated cell inhabitants embedded in an ECM and are capable of adhering to a sweeping diversity of surfaces with distinct biotic and abiotic compositions, including human tissue and medical expedients. Present-day applications of biofilms take account of the humiliation of toxic affluences in soil and water, the viable production of chemicals, and the generation of electricity. Bacterial biofilm is infectious in nature and can result in nosocomial infections. Lots of species of bacteria are able to communicate with one another throughout the biofilm development over a specific mechanism called quorum sensing. Bacterial biofilm construction is considered to be an up-and-coming microbial lifestyle in usual and artificial atmospheres and befalls on all surface types $[28,29]$. Some biofilm forming bacterias are, P. aeruginosa, Vibrio cholerae, Listeria monocytogenes, and E. coli. Temperature, $\mathrm{pH}$ differences, ultraviolet radiation, oxidization, metal ions and desiccation are some exterior issues against which biofilm provides protection to the bacteria. 
Additionally, biofilms are able to evade inherent and/or adaptive immune defences and avoid antimicrobial treatments by several appliances [30-32]. Fungi habitually flourish as biofilms, which are aggregated communities wrapped in a protective extracellular matrix. Fungal biofilms are communities of adherent cells bounded by an extracellular matrix. Fungi are also used for pollution removal, besides bacteria. Fungal biofilms help in the deprivation of environmental organic chemicals, from proteins to complex carbohydrates, lipids, aromatic hydrocarbons, pharmaceutical compounds, heavy metals, endocrine disrupting chemicals by means of wide array of intra-and extracellular enzymes $[33,35]$ and therefore it forms a significant group of microscopic communities in wastewater treatment plants [36]. Many medically important fungi produce biofilms, including Candida [37], Aspergillus [38], Cryptococcus [39], Trichosporon [40], Coccidioides [41], and Pneumocystis [42].

\section{Mixed culture biofilm}

Single microbial species or a combination of different microbial species which includes bacteria, algae, fungi etc, that attach tightly to one another and to biotic or abiotic surfaces to form biofilm [43-47]. Due to coexistence of multiple microbial species close proximity is formed which promotes interaction among its members. By the synergistic interactions between algae and prokaryotic microbial communities biological wastewater treatment processes can be improved. Increases in biomass activity, growth efficiency, and enzyme production is achieved by the effect of mixture of microorganisms. In mixed culture to overcome feedback regulation and catabolic repression the products of one microorganism act as substrate for the other. In an example of biofilms in sewage treatment, the association of Nitrosococcus sp and Nitrospira sp is proved beneficial [48]. By pure culture, there are several microbial processes that cannot be achieved. Also, in tempeh wastewater contains diverse gram-positive and gram-negative bacterial species, such as Enterobacter cloacae, Klebsiella pneumoniae,Klozaenae, Enterobacter agglomerans, Streptococcus Dysgalactiae, Lactobacillus casei, Enterococcus faecium, Staphylococcus epidermidis [49]. By providing additional oxygen from photosynthesis, microalgae help in improving the purification performance of bacterial systems and also decreases the total energy costs of direct or indirect oxygen supply [50].

\section{Undesirable biofilm}

In the treatment process biofilms can have both positive and negative treatment. For membrane filtration Membrane bioreactors (MBRs) and Membrane biofilm reactors (MBfRs) are used. Membrane biofouling in a moving bed biofilm reactor (MBBR) reduces permeate flow and can cause problems in membrane bioreactor (MBR) [51]. For large scale operations the irreversible fouling cannot be removed by cleaning therefore it is very difficult to manage [52]. The major reasons for the occurrence of biofouling is the production of membrane foulants by microorganisms present in the wastewater and colonization of membrane surfaces with microorganisms. For membrane fouling problem interactions and activities of microbial community in wastewater and on membrane surface should be well understood for developing novel solutions. Microorganisms and their organic products are the main reason for membrane fouling. By this fouling and the formation of biofilm the flux and permeability of the membrane is decreased [53]. Therefore, fouling needs to be kept in control, to decrease operational costs and increase membrane lifetime.

\section{Biofilm characterization approach both traditional and modern}

A complex, three-dimensional microbial community that grows at an interface and interacts with the surrounding environment is known as biofilm $[54,55]$. By sequestration and alteration of potentially toxic compounds, as a renewable aid in applications of waste, soil and water remediation is done potentially by biofilms [56-58]. With respect to its compatibility with the emerging biofilms the chemical composition of the filter media is very critical; its elemental composition should be assessed. To analyse the surface chemistry of a material, different techniques can be applied, for the detection and quantification of the elements in a filter medium. The elemental composition is measured at the parts per thousand range, empirical formulas, electronic state and chemical state of the elements that exist contained by a material [59].

\section{Traditional methods}

\section{Determination of viable cell numbers by plate count (Colony Forming Units/mlOrCfus)}

A standard quantification method is used to determine the number of viable cells called viable cell enumeration of $\mathrm{CFU} / \mathrm{ml}$ assay [60, 61]. Living cells are differentiated from dead cells and their enumeration without dyes or instrumentation hence separating the individual cells on an agar plate and growing colonies from cells, is the basic concept of this assay. It is noted that in a mixed culture bacteria are replicated at different rates. Consequently, the culture expansion may not be suitable as it will disrupt the ratio of cells from the original biofilm. To accommodate for slow colony forming bacteria the colony forming incubation time may need to be extended [62] (table 1).

\section{Determination of biofilm weight (Wet weight and dry weight)}

A digital weighing balance is used to determine the weight of biofilm in terms of dry weight and wet weight. The wet weight is measured after soft rinsing with distilled water; however, the dry weight is estimated by allowing it to dry under aseptic conditions in laminar flow until the execution of the constant weight of polypropylene and polystyrene filter media $[63,64]$. Contrariwise, natural filter media such as rock, granite or stone media, should be dried in the oven at $60{ }^{\circ} \mathrm{C}$ to attain constant weight [65]. The difference between the weight of medium with biofilm and that of medium without biofilm gives the weight of biofilm.

\section{Determination of the biofilm Optical Density (OD)}

The biofilm is also measured by the OD method. To ensure the removal of any material on their surface the filter media supporting biofilm are first rinsed with sterilized water. Then the biofilm is removed from the filter media in $0.9 \%$ saline by sonication for $15 \mathrm{~min}$. Finally, at $550 \mathrm{~nm}$ wavelength (OD550) using saline as blank the spectrophotometric absorbance of dissolved biofilms is recorded [63-65].

\section{Determination of heterotrophic plate count (HPC)}

The HPC concentration is determined by the conventional serial dilution method. The biofilm dissolved in $0.9 \%$ saline is serially diluted (up to $10^{-5}$ ) and then spread on the selective growth media plates and incubated at $37{ }^{\circ} \mathrm{C}$ for a specific time period (24-48 h). The microbial growth giving the impression on specific media is enumerated in terms of $\mathrm{HPC} / \mathrm{ml}$ (pathogen indicators). Further identification of pure cultures from these plates are done by observing colony morphology as well as microscopic and biochemical tests.

\section{Microscopic analysis of biofilms}

The truthful way of visualizing biofilms without disturbing their structure is provided by non-invasive microscopic technique. The traditional microscopic techniques used for imaging analysis of biofilm samples involve light microscopy (LM) and electron microscopy (SM). The most commonly used method for structural analysis is Scanning Electron Microscopy (SEM). Overall magnification of SEM can range from about 10-500,000 times, and can be used to develop a high resolution, magnified image of surface topography making this technique vital in the analysis of microscopic structures, including those of biofilms [66]. To understand formation and persistence, high resolution images can be gathered by SEM useful in evaluation of bacterial interaction, EPS organization and biofilm morphology [67-69].

\section{B. Advanced methods}

\section{Clone library technique}

Since the beginning of the 1990s cloning and sequencing of the $16 \mathrm{~S}$ rRNA gene have been comprehensively and effectively employed for the study of microbial biofilms, and this is still the most widely used technique [70]. The clone library method allows complete 16S rRNA sequencing and identification with very precise taxonomic studies of both cultured and uncultured microorganisms in biofilms, design of primers for PCR and probes for fluorescence in situhybridization (FISH) [71]. In combination with other advanced techniques, cloning 
and rRNA gene library construction have also been applied in wastewater treatment for the exploration of biofilm communities.

\section{Microbial fingerprinting methods}

Microbial fingerprinting methods marks a distinction between microorganisms and groups of microorganisms on the basis of their distinctive characteristics of a universal component of a biomolecule, such as phospholipids, DNA or RNA, providing the overall profile of a biofilm [72, 73]. Phospholipid fatty acid analysis (PLFA), denaturing gradient gel electrophoresis (DGGE) and terminal restriction fragment length polymorphism (T-RFLP) are included in this method. The mass of PLFAs in a biofilm sample is directly proportional to viable biomass as type and proportion of phospholipid are distinctive to different microorganisms and break down rapidly upon cell death; still they are structural components of all cell membranes. Some sets of organisms have unique or "signature" types of PLFA [74]. DGGE is a nucleic acid-based technique and is engaged to generate a genetic fingerprint of a complex microbial community [70]. T-RFLP is a nucleic acid-based method and delivers the profile of a microbial community, which is used to detect specific microbial populations [75].

\section{Fluorescence in situ hybridization (FISH)}

FISH is an excellent method for the identification, localization, visualization and quantification of non-cultured microorganisms in their microcosm. The most commonly used target molecules for FISH are 16S rRNA, 18S rRNA, 23S rRNA and mRNA Detection/Identification on any desired taxonomic level is enabled by the specificity of the fluorescent probe, from domain down to a resolution suitable for differentiating between individual species [76]. Digitalization/Manipulation of images can be achieved by a charged coupled device (CCD) and appropriate image analysis software, quantifying rRNA content can help to maintain record of microorganisms, and measurement of the activity of single cells in biofilms. While obtaining three-dimensional images with thick samples with a high background (sludge flocs, biofilms) CLSM is used with FISH analysis. In order to overcome some of its pitfalls like increase its sensitivity and upgradation, FISH can be combined with other techniques. Enabling bacteria to be mapped, FISH-based methods have revolutionized investigations into the morphology and microbial composition of biofilms [77].

\section{Next-generation sequencing (NGS) technology}

A unique DNA sequencing technology which transforms microbial ecology, explores deeper layers of microbial communities and is vital in presenting an unbiased view of the composition and diversity of communities [78] is developed at the Royal Institute of Technology called pyrosequencing, based on the sequencing-bysynthesis principle [79] and on the recognition of released pyrophosphate (PPi) during DNA synthesis [80]. In comparison to the first-generation Sanger sequencing technology this technology NGS platform such as Roche/454, Illumina/Solexa, Life/APG and HeliScope/HelicosBioSciences are much faster and less expensive [81]. The technique of pyrosequencing has no need for labelled primers, labelled nucleotides and gel electrophoresis. It has the potential advantages of accuracy, flexibility, parallel processing and easy automation. It has been effective for both confirmatory sequencing and de novo sequencing [80].

Table 1: Summary of methods for characterization of biofilms

\begin{tabular}{ll}
\hline Methods & $\begin{array}{l}\text { Specialized equipment } \\
\text { required }\end{array}$ \\
\hline $\begin{array}{l}\text { Plate Count, } \\
\text { Viable cell } \\
\text { enumeration }\end{array}$ & $\begin{array}{l}\text { Incubator-Consumables: } \\
\text { disposable petri plates, } \\
\text { culture flasks, suitable agar } \\
\text { and medium }\end{array}$ \\
& Compound, bright field \\
Light & microscope \\
Microscopy & \\
Fluorescent & $\begin{array}{l}\text { Bright field/Fluorescent } \\
\text { Microscope: Fluorescent stains, } \\
\text { Microscopy } \\
\text { and Staining }\end{array}$ \\
flibodies or endogenous \\
fonfocal & $\begin{array}{l}\text { Confocal Fluorescent } \\
\text { Microscope: Fluorescent }\end{array}$ \\
Fluorescent & $\begin{array}{l}\text { stains, antibodies or } \\
\text { endogenous fluorescent } \\
\text { proteins }\end{array}$ \\
&
\end{tabular}

Determination Analytical Balance: Lab oven of Dry Mass capable of reaching $100{ }^{\circ} \mathrm{C}$

Optical spectrophotometer

Density

Atomic Force Microscopy (AFM) SEM
Flow Chambers, Micropipette Aspiration and Centrifugation Devices

Scanning electron microscope: Sputtering Coater

Biofilm preparation Notes

Cells are removed from the

substrate, homogenized, resuspended in liquid medium, diluted, and aliquots are plated, incubated and counted.

Biofilm can be grown directly on a transparent substrate, such as a slide or cover slip, stained and observed directly.

Biofilm can be grown directly on a slide or coverslip, stained, and observed in situ. Biofilm is stained with view of the desired outcome. Can image in place biofilm (on a coverslip, e. g.). Cells must be labelled. Fluorophores can be selected according to a variety of purposes, such as distinguishing live and dead cells, staining nuclei/DNA, etc.

Film on substrate is dried, massed, then cleaned. Substrate is massed again.

ensure the removal of any material on their surface the filter media supporting biofilm are first rinsed with sterilized water. Then the biofilm is removed from the filter media in $0.9 \%$ saline by sonication for $15 \mathrm{~min}$

Bacterial adhesion, Mature Biofilm Morphology

Biofilm can be grown on a coverslip (or other substrate) and directly imaged on the microscope. Samples must be fixed, dried, and coated with metal (Pt-Pd).

\section{Notes}

Most readily adaptable to liquid/planktonic cultures. This method only quantifies live cells, and an assumption is made that each colony derives from one original cell. The differing metabolic states of living cells in the biofilm may complicate determination of accurate number of cells in the biofilm. Must be confirmed by cell mass or surface area.

Counting or observing mature biofilms is limited, as accumulation of extensive biofilm mass prevents observation of individual cells. Can be used in conjunction with dry mass measurements to acquire biofilm thickness and quantifying specific visual characteristics of the biofilm. Some stains are potential mutagens. Stain should be chosen carefully--not all stains penetrate the cell membrane, and not all are compatible with maintaining a living biofilm.

Bio volume can be calculated with appropriate software and computing capability. Usually requires a dedicated technician to run and maintain the instrument. Can image any cell or particle that has a fluorescent label that can be detected by the microscope. It is better used for structures and 3D architecture than counting cells. Can image within the thickness of the biofilm and assemble z-stacks. Film area should be measured; thickness can be measured to give dry mass per unit of wet volume.

The biofilm is also measured by the OD method. at $550 \mathrm{~nm}$ wavelength (OD550) using saline as blank the spectrophotometric absorbance of dissolved biofilms is recorded

AFM is suitable for a quantification of the interaction forces and can be provide a 3D surface profile

Toxic chemicals may be involved in some fixation techniques. Usually requires a maintenance contract and special housing conditions. 


\section{Alternative qualitative characterization methods}

By using scanning electrochemical microscopy (SECM) the topological structure and chemical properties of biofilm surfaces can be assessed [82,83]. Based on the distribution of reactive groups used to determine the distribution of extracellular polymeric substance (EPS) components at the biofilm surface this versatile technique can provide an extra dimension to 3D models of biofilms. Literature precedence exists to analyse biofilms with atomic force microscopy (AFM), although it is not commonly utilized currently. AFM would be useful in understanding biofilm characteristics such as roughness, topography, and stiffness; it can characterize the components on the underlying substratum as well as the substratum interactions [84]. But, requires specialized equipment costing more than $\$ 100 \mathrm{~K}$ and trained operators, like similar techniques. For effectiveness as a non-destructive method for greater understanding of biofilm aggregation, adhesion and EPS composition spectroscopic analyses of biofilm are becoming increasingly recognized. For providing similar data, Infrared spectroscopy delivers the vibrational information through the use of IR light, whereas Raman typically uses more energetic light, usually supplied by a near IR, visible, or ultraviolet laser. Despite some complications, with confocal scanning light microscopy (CSLM), or with specialized IR well-suited surfaces IR and Raman are good methods to use in aggregation with one another, [85-88].

\section{Biofilm reactors}

In modern water sanitation Biofilm reactors can be traced as its origination. Biofilms have led to the development of new and emerging biofilm reactors conducive to fundamentally based design approaches by making it significant by academic understanding, advances in the design, and mathematical modelling and its applications are fundamentally design and operation procedure for traditional biofilm reactors. All biofilm reactors have two characteristic processes (1) mass transfer and (2) biochemical conversion which influence biofilm structure and function. For these processes every biofilm reactor has common Compartments for optimisation.

\section{Moving bed biofilm reactors}

The MBBR has a two-(anoxic) or three-(aerobic) phase system with free floating plastic biofilm carrier which requires mechanical mixing for distribution of carriers throughout the tank. The process has submerged and completely mixed biofilm reactor and unit for separation of liquid-solids [89]. A series of pollutant loading and bulk phase external carbon sources in denitrification and dissolved oxygen concentrations in carbon-oxidation or nitrification MBBRs have been applied, and response of the system is evaluated. As the activated sludge process MBBR process is also capable of meeting similar treatment objectives for carbon oxidation, nitrification, and denitrification but the MBBR makes use of a smaller tank volume. For biofilm thickness control it does not require a special operational cycle because MBBR is a continuously flowing process. In the existing municipal wastewater treatment plant, the MBBR is well suited for retrofit installation. The plan's ratio with (length to width) L: W greater than 1.5:1 results in nonuniform distribution of the biofilm carriers. MBBRs contain a plastic biofilm carrier which gives up to $67 \%$ of the liquid volume. To allow treated effluent to flow to the next treatment step, screens are typically installed with one MBBR wall while retaining the free-moving plastic biofilm carriers. To evenly distribute the plastic biofilm carriers and meet process oxygen requirements Aerobic MBBRs use a diffused aeration system. On the other hand, in anoxic MBBRs there are no process oxygen requirements so it has mechanical mixers to evenly distribute the plastic biofilm carriers. For meeting basic secondary treatment standards medium-rare MBBRs are designed, typically

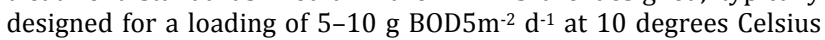
depending on the type of liquid-solid separation.

\section{Biologically active filters}

BAFs have a structure of natural mineral or random plastic media which supports biofilm growth and also serves as a filtration medium. Backwashing helps in removing solids accumulated from filtration and biochemical transformation. BAF configuration and backwash regimes influenced by media density. Preliminary and primary treatment are required by BAF influent. For secondary and tertiary treatment, downflow BAFs with media heavier than water include the Biocarbones process and packed-bed tertiary denitrification filters such as the Tetra Denites process. Using an intermittent counter-current flow these BAFs are backwashed. InfilcoDegremontBiofor process in upflow BAFs with media heavier than water have been used for secondary and tertiary treatment. To provide area for biofilm development and filtration, these processes use a floating bed of media. To meet treatment objectives, flow and backwashing regimes, media selection is integral. Media can be categorized as mineral media and plastic media. In most cases, plastic media is buoyant and mineral media is denser than water. During backwashing and chemical degradation by constituents in municipal wastewater, the media needs to resist breakdown from abrasion caused by them. BAFs designed for removal of carbon oxidation and suspended solids in secondary treatment typically have volumetric BOD loading rates in the range of $1.5-6 \mathrm{~kg} \mathrm{~m}^{-3} \mathrm{~d}^{-1}$.

\section{Expanded and fluidized bed biofilm reactors}

Expanded bed biofilm reactors (EBBRs) and FBBRs use small media particles that are suspended in vertically flowing wastewater, so that the media becomes fluidized and the bed expands. Individual particles become suspended once the drag force of the relatively fast flowing wastewater $\left(30-50 \mathrm{mh}^{-1}\right)$ overcomes gravity and they are separated. In municipal applications, fluidized beds are typically used for tertiary denitrification. When treating groundwater or industrial wastewater, FBBRs are used for the removal of oxidized contaminants such as nitrate and perchlorate. Suspension of the media maximizes the contact surface between microorganisms and wastewater. It also increases treatment efficiency by improving mass transfer because there is significant relative motion between the biofilm and flowing wastewater. Silica sand $(0.3-0.7 \mathrm{~mm}$ diameter) and granular activated carbon (GAC; $0.6-1.4 \mathrm{~mm}$ ) are typically used. Other materials, however, have been used at pilot scale, such as $0.7-1.0 \mathrm{~mm}$ glassy coke [90], which is one of the key advantages of this process technology. In a study of tertiary nitrification of activated sludge-settled effluent using a pilot-scale EBBR, [91] found that the process also removed up to 56\% CBOD and $62 \%$ TSS from the influent stream. Removal of these materials was attributed to the activities of protozoa (free-living and stalked) and metazoa (rotifers, nematodes, and oligochaetes)

\section{Rotating biological contactors}

$\mathrm{RBC}$ is an efficient attached growth system that purifies wastewater from different industries, namely food and beverage, refinery and petrochemical. In addition, it is efficient in purifying municipal wastewater, landfill leachate and lagoon effluent. When an average effluent waste water quality standard is less than or equal to $30 \mathrm{mg} \mathrm{l}^{-}$ ${ }^{1} \mathrm{BOD}$ the RBC process has been applied. The RBC contains a horizontal shaft, in which a cylindrical, synthetic media bundle is mounted. The bundled media is partially submerged and slowly rotates to expose the biofilm to air (when not submerged) and to substrate in the bulk of the liquid (when submerged). The RBC effluent stream is removed by liquid-solids separation units to detach biofilm fragments suspended. By reduced life cycle costs, less sludge production, less space requirement, ease of operation and high process stability with load variations as well as high effluent quality with regard to both biological oxygen demand (BOD) and nutrients, the RBC system has an edge over suspended growth systems.

\section{Trickling filters}

A three-phase biofilm reactor with secure carriers is called a Trickling Filter. Past a distribution system wastewater enters the bioreactor, trickles downhill over the biofilm surface, and in the third phase air circulates where it diffuses through the flowing liquid and into the biofilm. An influent water distribution system, containment structure, rock or plastic media, an underdrain and ventilation system are the components of Trickling Filter. A net production of total suspended solids is the result of treatment of wastewater using a trickling filter. And so, liquid-solids separation is required, this is achieved with circular or rectangular secondary clarifiers. The Trickling Filter process generally includes an influent/recirculation pump station, the 
Trickling Filter(s), and liquid-solids separation unit(s). Ideal Trickling Filter media encourage ventilation and be responsible for a high specific surface area, low cost, high permanency, and high enough porosity to avoid clogging [92]. Trickling Filter media types include rock, random (synthetic), vertical flow, and cross-flow (synthetic). Fixed-nozzle and rotary distributors are the two types of Trickling Filter distribution systems. Microorganisms forming on the packing material surface grow in biofilm and degrade the pollutants from the effluent.

\section{CONCLUSION}

Nutrients for growth are anchorage by Biofilm. Complex organics can be easily broken-down into metabolized substrates using enzymes beneath the biofilm matrix and also felicitate horizontal gene transfer. At one front where this biofilm strategies help in the treatment of waste water on the other hand it is difficult to remove these from environment as well as their growth is not only affected by the environment surrounding but is also affected by the native microflora. This study presents comparative data screening the benefits of biofilm treatment processes, describing their use in several stages of the wastewater treatment process. This study is important because, for improved scheming of these biofilm-based wastewater treatment strategies, knowledge about the microorganism involved, stages of treatment and factors affecting the treatment process are vital.

\section{FUNDING}

Nil

\section{AUTHORS CONTRIBUTIONS}

All the authors have contributed equally.

\section{CONFLICT OF INTERESTS}

Declared none

\section{REFERENCES}

1. Hentzer M, Eberl L, Givskov M. Transcriptome analysis of Pseudomonas aeruginosa biofilm development: anaerobic respiration and iron limitation. Biofilms. 2005;2(1):37-61. doi: 10.1017/S1479050505001699.

2. Rajan S, Saiman L. Pulmonary infections in patients with cystic fibrosis. Semin Respir Infect. 2002;17(1):47-56. doi: 10.1053/srin.2002.31690, PMID 11891518.

3. Abdel-Aziz SM, AA. Bacterial biofilm: dispersal and inhibition strategies. Scholarena J Biotechnol 2014;1(1):105. doi: 10.18875/2375-6713.1.105.

4. Hoiby N, Ciofu O, Johansen HK, Song ZJ, Moser C, Jensen PO, Molin S, Givskov M, Tolker Nielsen T, Bjarnsholt T. The clinical impact of bacterial biofilms. Int J Oral Sci. 2011;3(2):55-65. doi: 10.4248/IJOS11026, PMID 21485309.

5. Pavithra D, Doble M. Biofilm formation, bacterial adhesion and host response on polymeric implants--issues and prevention. Biomed Mater. 2008;3(3):034003. doi: 10.1088/17486041/3/3/034003, PMID 18689922.

6. Trentin DS, Giordani RB, Macedo AJ. Pathogenic bacterial biofilms: general aspects, clinical importance and combat strategies. Rev Liberato. 2013;14:113-238.

7. Schmidt J, Musken M, Becker T, Magnowska Z, Bertinetti D, Moller S, Zimmermann B, Herberg FW, Jansch L, Haussler S. The pseudomonas aeruginosa chemotaxis methyltransferase CheR1 impacts on bacterial surface sampling. PLOS ONE. 2011;6(3):e18184. doi: 10.1371/journal.pone.0018184. PMID 21445368.

8. Stoodley P, Sauer K, Davies DG, Costerton JW. Biofilms as complex differentiated communities. Annu Rev Microbiol. 2002;56:187-209. doi: 10.1146/annurev.micro.56.012302.160705, PMID 12142477.

9. Kuchma SL, O'Toole GA. Surface-induced and biofilm-induced changes in gene expression. Curr Opin Biotechnol. 2000;11(5):42933. doi: 10.1016/s0958-1669(00)00123-3, PMID 11024358.

10. Donlan RM, Costerton JW. Biofilms: survival mechanisms of clinically relevant microorganisms. Clin Microbiol Rev. 2002;15(2):167-93. doi: 10.1128/CMR.15.2.167-193.2002, PMID 11932229.
11. Naves P, del Prado G, Huelves L, Rodriguez Cerrato V, Ruiz V, Ponte MC, Soriano F. Effects of human serum albumin, ibuprofen and N-acetyl-L-cysteine against biofilm formation by pathogenic Escherichia coli strains. J Hosp Infect. 2010;76(2):165-70. doi: 10.1016/j.jhin.2010.05.011. PMID 20615578.

12. Flemming HC, Wingender J. The biofilm matrix. Nat Rev Microbiol. 2010;8(9):623-33. doi: 10.1038/nrmicro2415, PMID 20676145.

13. Drescher K, Nadell CD, Stone HA, Wingreen NS, Bassler BL. Solutions to the public goods dilemma in bacterial biofilms. Curr Biol. 2014;24(1):50-5. doi: 10.1016/j.cub.2013.10.030, PMID 24332540.

14. Donlan RM. Biofilms: microbial life on surfaces. Emerg Infect Dis. 2002;8(9):881-90. doi: 10.3201/eid0809.020063, PMID 12194761.

15. Baselga R, Albizu I, Amorena B. Staphylococcus aureus capsule and slime as virulence factors in ruminant mastitis. A review. Vet Microbiol. 1994;39(3-4):195-204. doi: 10.1016/03781135(94)90157-0, PMID 8042268.

16. Hong SH, Lee J, Wood TK. Engineering global regulator Hha of Escherichia coli to control biofilm dispersal. Microb Biotechnol. 2010;3(6):717-28. doi: 10.1111/j.1751-7915.2010.00220.x, PMID 21255366.

17. Kolodkin Gal I, Romero D, Cao S, Clardy J, Kolter R, Losick RD. Damino acids trigger biofilm disassembly. Science. 2010;328(5978):627-9. doi: 10.1126/science.1188628, PMID 20431016.

18. Hall Stoodley L, Costerton JW, Stoodley P. Bacterial biofilms: from the natural environment to infectious diseases. Nat Rev Microbiol. 2004;2(2):95-108. doi: 10.1038/nrmicro821, PMID 15040259.

19. Prakash B, Veeregowa BM, Krishnappa G. Biofilms: a survival strategy of bacteria. Curr Sci. 2003;85(9):1299-307.

20. Simoes M, Pereira MO, Sillankorva S, Azeredo J, Vieira MJ. The effect of hydrodynamic conditions on the phenotype of Pseudomonas fluorescens biofilms. Biofouling. 2007;23(3-4):249-58. doi: 10.1080/08927010701368476, PMID 17653934.

21. Xiong Y, Liu Y. Biological control of microbial attachment: a promising alternative for mitigating membrane biofouling. Appl Microbiol Biotechnol. 2010;86(3):825-37. doi: 10.1007/s00253-010-2463-0, PMID 20169341.

22. Zhao K, Tseng BS, Beckerman B, Jin F, Gibiansky ML, Harrison JJ, Luijten E, Parsek MR, Wong GCL. Psl trails guide exploration and microcolony formation in Pseudomonas aeruginosa biofilms. Nature. 2013;497(7449):388-91. doi: 10.1038/nature12155, PMID 23657259.

23. Das T, Sehar S, Manefield M. The roles of extracellular DNA in the structural integrity of extracellular polymeric substance and bacterial biofilm development. Environ Microbiol Rep. 2013;5(6):778-86. doi: 10.1111/1758-2229.12085, PMID 24249286.

24. Mulcahy H, Charron Mazenod L, Lewenza S. Extracellular DNA chelates cations and induces antibiotic resistance in Pseudomonas aeruginosa biofilms. PLOS Pathog. 2008;4(11):e1000213. doi: 10.1371/journal.ppat.1000213. PMID 19023416.

25. Kerchove AJ, Elimelech M. Calcium and magnesium cations enhance the adhesion of motile and nonmotile Pseudomonas aeruginosa on alginate films. Langmuir. 2008;24(7):3392-9. doi: 10.1021/la7036229, PMID 18302437.

26. Das T, Sehar S, Koop L, Wong YK, Ahmed S, Siddiqui KS, Manefield M. Influence of calcium in extracellular DNA mediated bacterial aggregation and biofilm formation. PLOS ONE. 2014;9(3):e91935. doi: 10.1371/journal.pone.0091935. PMID 24651318.

27. Sarkisova S, Patrauchan MA, Berglund D, Nivens DE, Franklin MJ. Calcium-induced virulence factors associated with the extracellular matrix of mucoid Pseudomonas aeruginosa biofilms. J Bacteriol. 2005;187(13):4327-37. doi: 10.1128/JB.187.13.4327-4337.2005, PMID 15968041.

28. Lindsay D, von Holy A. Bacterial biofilms within the clinical setting: what healthcare professionals should know. J Hosp Infect. 2006;64(4):313-25. doi: 10.1016/j.jhin.2006.06.028, PMID 17046102.

29. Flemming HC, Wingender J, Szewzyk U, Steinberg P, Rice SA, Kjelleberg S. Biofilms: an emergent form of bacterial life. Nat 
Rev

Microbiol.

2016;14(9):563-75.

doi: 10.1038/nrmicro.2016.94, PMID 27510863.

30. Roilides E, Simitsopoulou M, Katragkou A, Walsh TJ. How biofilms evade host defenses. Microbiol Spectr. 2015;3(3):1-10. doi: 10.1128/microbiolspec.MB-0012-2014, PMID 26185085

31. Domenech M, Ramos Sevillano E, Garcia E, Moscoso M, Yuste J. Biofilm formation avoids complement immunity and phagocytosis of Streptococcus pneumoniae. Infect Immun. 2013;81(7):2606-15. doi: 10.1128/IAI.00491-13, PMID 23649097.

32. Stewart PS. Antimicrobial tolerance in biofilms. Microbiol Spectr. 2015;3(3):1-30. doi: 10.1128/microbiolspec.MB-00102014

33. Harms H, Schlosser D, Wick LY. Untapped potential: exploiting fungi in bioremediation of hazardous chemicals. Nat Rev Microbiol. 2011;9(3):177-92. doi: 10.1038/nrmicro2519, PMID 21297669.

34. Naghdi M, Taheran M, Brar SK, Kermanshahi Pour A, Verma M, Surampalli RY. Removal of pharmaceutical compounds in water and wastewater using fungal oxidoreductase enzymes. Environ Pollut. 2018;234:190-213. doi 10.1016/j.envpol.2017.11.060. envpol.2017.11.060.

35. Siddiquee S, Rovina K, Azad SA. Heavy metal contaminants removal from wastewater using the potential filamentous fungi biomass: a review. J Microb Biochem Technol 2005;07(6):38493. doi: 10.4172/1948-5948.1000243.

36. Zhang H, Feng J, Chen S, Li B, Sekar R, Zhao Z, Jia J, Wang Y, Kang P. Disentangling the drivers of diversity and distribution of fungal community composition in wastewater treatment plants across spatial scales. Front Microbiol. 2018;9:1291. doi: 10.3389/fmicb.2018.01291, PMID 29967600.

37. Finkel JS, Mitchell AP. Genetic control of Candida albicans biofilm development. Nat Rev Microbiol. 2011;9(2):109-18. doi: 10.1038/nrmicro2475, PMID 21189476

38. Beauvais A, Muller FM. Biofilm formation in Aspergillus fumigatus. In: Latge JP, Steinbach WJ, editors. Aspergillus fumigatus and aspergillosis. Washington, DC: ASM Press; 2009. p. 149-57.

39. Martinez LR, Casadevall A. Cryptococcus neoformans biofilm formation depends on surface support and carbon source and reduces fungal cell susceptibility to heat, cold, and UV light. Appl Environ Microbiol. 2007;73(14):4592-601. doi: 10.1128/AEM.02506-06, PMID 17513597

40. Di Bonaventura G, Pompilio A, Picciani C, Iezzi M, D’Antonio D, Piccolomini R. Biofilm formation by the emerging fungal pathogen Trichosporon asahii: development, architecture, and antifungal resistance. Antimicrob Agents Chemother. 2006;50(10):3269-76, doi: 10.1128/AAC.00556-06, PMID 17005804.

41. Davis LE, Cook G, Costerton JW. Biofilm on ventriculoperitoneal shunt tubing as a cause of treatment failure in Coccidioidal meningitis. Emerg Infect Dis. 2002;8(4):376-9. doi: 10.3201/eid0804.010103, PMID 11971770.

42. Cushion MT, Collins MS, Linke MJ. Biofilm formation by Pneumocystis spp. Eukaryot Cell. 2009;8(2):197-206. doi: 10.1128/EC.00202-08, PMID 18820078

43. Tomaras AP, Dorsey CW, Edelmann RE, Actis LA. Attachment to and biofilm formation on abiotic surfaces by Acinetobacter baumannii: involvement of a novel chaperone-usher pili assembly system. Microbiology (Reading). 2003;149(12):347384. doi: 10.1099/mic.0.26541-0, PMID 14663080.

44. Bogino PC, Oliva Mde L, Sorroche FG, Giordano W. The role of bacterial biofilms and surface components in plant-bacterial associations. Int J Mol Sci. 2013;14(8):15838-59. doi: 10.3390/ijms140815838, PMID 23903045

45. Silva VO, Soares LO, Silva Junior A, Mantovani HC, Chang YF Moreira MA. Biofilm formation on biotic and abiotic surfaces in the presence of antimicrobials by Escherichia coli Isolates from cases of bovine mastitis. Appl Environ Microbiol. 2014;80(19):6136-45. doi: 10.1128/AEM.01953-14, PMID 25063668

46. Costa Orlandi CB, Sardi JCO, Pitangui NS, De Oliveira HC, Scorzoni L, Galeane MC, Medina Alarcon KP, Melo WCMA, Marcelino MY, Braz JD, Fusco Almeida AM, Mendes Giannini MJS. Fungal biofilms and polymicrobial diseases. J Fungi (Basel). 2017;3(2):22. doi: 10.3390/jof3020022, PMID 29371540.
47. Raghupathi PK, Liu W, Sabbe K, Houf K, Burmølle M, Sørensen SJ. Synergistic interactions within a multispecies biofilm enhance individual species protection against grazing by a pelagic protozoan. Front Microbiol. 2017;8:2649. doi: 10.3389/fmicb.2017.02649, PMID 29375516.

48. Juretschko S, Timmermann G, Schmid M, Schleifer KH, Pommerening Roser A, Koops HP, Wagner M. Combined molecular and conventional analyses of nitrifying bacterium diversity in activated sludge: Nitrosococcus mobilis and nitrospira-like bacteria as dominant populations. Appl Environ Microbiol. 1998;64(8):3042-51. doi: 10.1128/AEM.64.8.30423051.1998, PMID 9687471

49. Nout MJR, Rombouts FM. Recent developments in tempe research. I Appl Bacteriol 1990;69(5):609-33. doi 10.1111/j.1365-2672.1990.tb01555.x.

50. Quijano G, Arcila JS, Buitroón G. Microalgal-bacterial aggregates: applications and perspectives for wastewater treatment. Biotechnol Adv. 2017;35(06):772-81. doi: 10.1016/j.biotechadv.2017.07.003, PMID 28694179

51. Kimura K, Yamato N, Yamamura H, Watanabe Y. Membrane fouling in pilot-scale membrane bioreactors (MBRs) treating municipal wastewater. Environ Sci Technol. 2005;39(16):6293-9. doi: 10.1021/es0502425, PMID 16173595.

52. Wang YQ, Wang T, Su YL, Peng FB, Wu H, Jiang ZY. Remarkable reduction of irreversible fouling and improvement of the permeation properties of poly (ether sulfone) ultrafiltration membranes by blending with pluronic F127. Langmuir 2005;21(25):11856-62. doi: 10.1021/la052052d, PMID 16316125.

53. Hirani ZM, Bukhari Z, Oppenheimer J, Jjemba P, LeChevallier MW, Jacangeloani JG. Impact of MBR cleaning and breaching on passage of selected microorganisms and subsequent inactivation by free chlorine. Water Res. 2014;57:14313-24. doi: 10.1016/j.watres.2014.03.038, PMID 24735904.

54. McBain AJ. Chapter 4: In vitro biofilm models: an overview. Adv Appl Microbiol. 2009;69:99-132. doi: 10.1016/S00652164(09)69004-3, PMID 19729092.

55. Vert M, Doi Y, Hellwich KH, Hess M, Hodge P, Kubisa P, Rinaudo M, Schué F. Terminology for biorelated polymers and applications (IUPAC Recommendations 2012). Pure Appl Chem. 2012;84(2):377-410, doi: 10.1351/PAC-REC-10-12-04.

56. Ateia M. In-situ biological water treatment technologies for environmental remediation: a review. J Bioremediat Biodegrad 2015;07(3). doi: 10.4172/2155-6199.1000348.

57. Amulya K, Dahiya Shikha MSV. Building a bio-based economy through waste remediation: innovation towards a sustainable future. Bioremediation Bioeconomy. Netherlands: Elsevier; 2016. p. 497-521. doi: 10.1016/B978-0-12-802830-8.00019-8.

58. Singh R, Paul D, Jain RK. Biofilms: limplications in bioremediation. Trends Microbiol. 2006;14(9):389-97. doi: 10.1016/j.tim.2006.07.001.tim.2006.07.001. PMID 16857359.

59. Crist BV. XPS handbook: elements and native oxides. New York: John Wiley and Sons; 2000. p. 458.

60. Adetunji VO, Odetokun IA. Assessment of biofilm in E. col 0157:H7 and salmonella strains: influence of cultural conditions. Am J Food Technol. 2012;7(10):582-95. doi: 10.3923/ajft.2012.582.595

61. Pettit RK, Weber CA, Kean MJ, Hoffmann H, Pettit GR, Tan R, Franks KS, Horton ML. Microplate alamar blue assay for staphylococcus epidermidis biofilm susceptibility testing. Antimicrob Agents Chemother. 2005;49(7):2612-7. doi: 10.1128/AAC.49.7.2612-2617.2005, PMID 15980327.

62. Cloete TE, Brozel VS, Von Holy AV. Practical aspects of biofouling control in industrial water systems. International Biodeterioration Biodegradation. 1992;29(3-4):299-341. doi: 10.1016/0964-8305(92)90050-X.

63. Naz I, Batool SA, Ali N, Khatoon N, Atiq N, Hameed A, Ahmed S. Monitoring of growth and physiological activities of biofilm during succession on polystyrene from activated sludge under aerobic and anaerobic conditions. Environmental Monitoring and Assessment. 2013;185(8):6881-92. doi: 10.1007/s10661013-3072-z, PMID 23361646

64. Khatoon N, Naz I, Ali MI, Ali N, Jamal A, Hameed A, Ahmed S. Bacterial succession and degradative changes by biofilm on 
plastic medium for wastewater treatment. J Basic Microbiol. 2014;54(7):739-49. doi: 10.1002/jobm.201300162, PMID 24115187.

65. Naz I, Sehaer S, Perveen I, Saroj DP, Ahmed S. Physiological activities associated with biofilm growth in attached and suspended growth bioreactors under aerobic and anaerobic conditions. Environ Technol. 2015;36(13-16):1657-71. doi: 10.1080/09593330.2014.1003614, PMID 25609155.

66. Arnold JW, Bailey GW. Surface finishes on stainless steel reduce bacterial attachment and early biofilm formation: scanning electron and atomic force microscopy study. Poult Sci. 2000;79(12):1839-45. doi: 10.1093/ps/79.12.1839, PMID 11194050.

67. Baum MM, Kainovic A, O"Keeffe T, Pandita R, McDonald K, Wu $\mathrm{S}$, Webster P. Characterization of structures in biofilms formed by a Pseudomonas fluorescens isolated from soil. BMC Microbiol. 2009;9:1-13103. doi: 10.1186/1471-2180-9-103, PMID 19460161.

68. Holling N, Dedi C, Jones CE, Hawthorne JA, Hanlon GW, Salvage JP, Patel BA, Barnes LM, Jones BV. Evaluation of environmental scanning electron microscopy for analysis of Proteus mirabilis crystalline biofilms in situ on urinary catheters. FEMS Microbiol Lett. 2014;355(1):20-7. doi: 10.1111/15746968.12451, PMID 24786314.

69. Hung C, Zhou Y, Pinkner JS, Dodson KW, Crowley JR, Heuser J, Chapman MR, Hadjifrangiskou M, Henderson JP, Hultgren SJ. Escherichia coli biofilms have an organized and complex extracellular matrix structure. mBIOio. 2013;4(5):110e00645-13. doi. org/10.1128/mBio.00645-13doi: 10.1128/mBio.00645-13, PMID 24023384.

70. DeSantis TZ, Brodie EL, Moberg JP, Zubieta IX, Piceno YM, Andersen GL. High-density universal $16 \mathrm{~S}$ rRNA microarray analysis reveals broader diversity than typical clone library when sampling the environment. Microbial Ecology. 2007;53(3):371-83. doi: 10.1007/s00248-006-9134-9, PMID 17334858.

71. Sanz JL, Kochling T, Sanz JL, Kochling T. Molecular biology techniques used in wastewater treatment: an overview. Process Biochemistry. 2007;42(2):119-33. doi: 10.1016/j.procbio.2006.10.003.

72. Rastogi G, Sani RK. Molecular techniques to assess microbial community structure, function, and dynamics in the environment. In: Ahmad, editors. Microbes and microbial technology: agricultural and environmental applications. New York: Springer; 2011. p. 29-57.

73. Thies JE. Soil microbial community analysis using terminal restriction fragment length polymorphisms. Soil Science Society America J. 2007;71(2):579-91. doi: 10.2136/sssaj2006.0318.

74. Hedrick DB, Peacock A, Stephen JR, Macnaughton SJ, Bruggemann J, White DC. Measuring soil microbial community diversity using polar lipid fatty acid and denaturing gradient gel electrophoresis data. J Microbiol Methods. 2000;41(3):23548. doi: 10.1016/s0167-7012(00)00157-3, PMID 10958969.

75. Malik S, Beer M, Megharaj M, Naidu R. The use of molecular techniques to characterize the microbial communities in contaminated soil and water. Environ International. 2008;34(2):265-76. doi: 10.1016/j.envint.2007.09.001, PMID 18083233.

76. Amann RI, Binder BJ, Olson RJ, Chisholm SW, Devereux R, Stahl DA. Combination of 16S rRNA-targeted oligonucleotide probes with flow cytometry for analyzing mixed microbial populations. Applied Environmental Microbiology. 1990;56(6):1919-25. doi: 10.1128/aem.56.6.1919-1925.1990, PMID 2200342.

77. Moter A, Gobel UB. Fluorescence in situ hybridization (FISH) for direct visualization of microorganisms. J Microbiol Methods. 2000;41(2):85-112. doi: 10.1016/s0167-7012(00)00152-4, PMID 10991623.
78. Zwolinski MD. DNA sequencing: strategies for soil microbiology. Soil Science Society of America Journal. 2007;71(2):592-600. doi: 10.2136/sssaj2006.0125.

79. Fakruddin M, Chowdhury A, Hossain MN, Mannan KS, Mazumdar M. Pyrosequencing-principles and applications. Int J Life Sci Pharm Res. 2012;2(2):65-76.

80. Ronaghi M. Pyrosequencing sheds light on DNA sequencing. Genome Research. 2001;11(1):3-11. doi: 10.1101/gr.11.1.3, PMID 11156611.

81. Metzker ML. Sequencing technologies- the next generation. Nature Reviews Genetics. 2010;11(1):31-46. doi: 10.1038/nrg2626, PMID 19997069.

82. Vahid Dastjerdi EV, Abdolazimi Z, Ghazanfarian M, Amdjadi P, Kamalinejad M, Mahboubi A. Effect of punica granatum L. flower water extract on five common oral bacteria and bacterial biofilm formation on orthodontic wire. Iran J Public Health. 2014;43(12):1688-94. PMID 26171362.

83. Pompilio A, Crocetta V, Pomponio S, Fiscarelli E, Di Bonaventura G. In vitro activity of colistin against biofilm by Pseudomonas aeruginosa is significantly improved under "cystic fibrosis-like" physicochemical conditions. Diagn Microbiol Infect Dis. 2015;82(4):318-25. doi: 10.1016/j.diagmicrobio.2015.01.006. PMID 26004353.

84. Beech IB, Smith JR, Steele AA, Penegar I, Campbell SA. The use of atomic force microscopy for studying interactions of bacterial biofilms with surfaces. Colloids and Surfaces B: Biointerfaces. 2002;23(2-3):231-47. doi: 10.1016/S09277765(01)00233-8.

85. Bodelon G, Garcia VM, Puente VL, Hill EH, Hamon C, Sanz Ortiz MN Bodelon G, Montes Garcia V, Lopez Puente V, Hill EH, Hamon C, Sanz Ortiz MN, Rodal Cedeira S, Costas C, Celiksoy S, Perez Juste I, Scarabelli L, La Porta A, Perez Juste J, Pastoriza Santos I, Liz Marzan LM. Detection and imaging of quorum sensing in Pseudomonas aeruginosa biofilm communities by surface-enhanced resonance Raman scattering. Nature Material. 2016;15(11):1203-11. doi: 10.1038/nmat4720, PMID 27500808.

86. Bosch A, Serra D, Prieto C, Schmitt J, Naumann D, Yantorno O. Characterization of Bordetella pertussis growing as biofilm by chemical analysis and FT-IR spectroscopy. Appl Microbiol Biotechnol. 2006;71(5):736-47. doi: 10.1007/s00253-0050202-8, PMID 16292646.

87. Muhamadali H, Chisanga M, Subaihi A, Goodacre R. Combining Raman and FT-IR spectroscopy with quantitative isotopic labeling for differentiation of E. coli cells at community and single cell levels. Anal Chem. 2015;87(8):4578-86. doi: 10.1021/acs.analchem.5b00892, PMID 25831066.

88. Reuben S, Banas K, Banas A, Swarup S. Combination of synchrotron radiation-based Fourier transforms infrared microspectroscopy and confocal laser scanning microscopy to understand spatial heterogeneity in aquatic multispecies biofilms. Water Res. 2014;64:123-33. doi: 10.1016/j.watres.2014.06.039. PMID 25046376.

89. Odegaard H. Innovations in wastewater treatment: the moving bed biofilm process. Water Science and Technology. 2006;53(9):17-33. doi: 10.2166/wst.2006.284, PMID 16841724.

90. McQuarrie J, Dempsey MJ, Boltz JP, Johnson B. The expanded bed biofilm reactor (EBBR)-an innovative biofilm approach for tertiary nitrification. San Diego, CA, 13-17 October 13-17. Alexandria, VA: Water Environment Federation; 2007.

91. Dempsey MJ, Porto I, Mustafa M, Rowan AK, Brown A, Head IM. The expanded bed biofilter: Ccombined nitrification, solids destruction, and removal of bacteria. Water Science and Technology. 2006;54(8):37-46. doi: 10.2166/wst.2006.739, PMID 17163011.

92. Metcalf, Eddy. Wastewater Eengineering: Ttreatment and Rreuse. 4th edn. New York: McGraw-Hill; 2003. 